\title{
The New Pyrenees: Contemporary Conflicts around Patrimony, Resources and Urbanization
}

\author{
I. Vaccaro \\ McGill University \\ O. Beltran \\ Universitat de Barcelona
}

\begin{abstract}
In the last twenty years the Pyrenean social landscape has experienced a significant change associated with shifts on the uses of its natural resources. Communities previously characterized by their high rates of depopulation are now in a process of relative demographic recovery. This change is associated to a shift from primary economic activities such as ranching, timber extraction or agriculture to an economic model based on leisure and services. In other words, the current Pyrenees are not dominated by agro-ranching practices. Nowadays the range is increasingly occupied by economic and social initiatives devoted to foster tourism and to cover the needs of visitors. In Spain this change has connected areas of the periphery of the countryside with its urban markets. It has moved the area from a set of marginal and unprofitable economic activities to a highly profitable market based on seasonal tourism and territorial speculation. The economic and symbolic reconstruction of the mountains from pastures into ski runs, for instance, has revealed all their economic potential in this globalized era of ours. This paper is focused in the Pallars Sobira, a Western district of the Catalan Pyrenees. It explores the consequences of this reconfiguration of the natural resources of an area. Nature becomes patrimony: it is either protected through conservation policies designed by the state, or exploited by local or external corporations. In any case, these recent changes are having significant impacts on settlement patterns, community identity, and public policies.

(Keywords: Pyrenees, landscape, rural demography, development)
\end{abstract}

In the year 2003 the Generalitat de Catalunya, regional government of northeast Spain, declared the High Pyrenees Natural Park (PNAP). The creation of the PNAP, that was designed to become the flagship of the Catalan network of protected areas, resulted from the explicit acknowledgment of the relationships between the environmental values that it intended to protect with the historical local uses of the territory. The landscapes contained in the park are the material manifestation of a specific historical relationship between human groups and biophysical environment.

The Pallars Sobirà district is one of the areas most affected by the conservationist wave. In the year 2007 the Pallars Sobirà, with a total surface of $1,378 \mathrm{~km} 2$, had $69.4 \%$ of its territory under some type of conservation policy, $55.2 \%$ being part of the PNAP. This extraordinarily high concentration of protected areas in these valleys attracted our attention. The fact that this district of the Pyrenees also has one of the higher concentrations of collective property (communal or public) only makes the picture more intricate and interesting.

This intriguing situation is the outcome of a convoluted history. The mountains, a traditional peripheral area of the emerging nation-states of the 18th and 19th century, did not fare well with the advent of modernity. To understand the social and ecological features of the current landscapes we need to take a look at the demographic history, the succession of state political initiatives, the effects of traditional practices, and the sequence of industrial schemes that have affected the territory of the Pallars Sobirà.

This is then a privileged setting to study the interactions between local communities with their managerial, tenure and value systems, and external inputs such as state policies, market economy or urban values. This is why we designed a comprehensive research project covering five different areas of the district: the Àneu Valleys, the municipalities of Lladorre and Espot, the two sides of the Baix Pallars, and the Àssua Valley. Each one of these locales presents a different combination of variables: some of these areas are booming with second residences; some are covered by protected areas; some are still experiencing the effects of massive depopulation; some have functioning ski resorts while others have abandoned ones; some have dynamic common property institutions; and some are exclusively managed by public institutions (Vaccaro and Beltran 2007).

The Pallars Sobirà experienced the crises of the agrarian, subsistence oriented, lifestyle. Its rural households used to practice a diversified agro-ranching way of life, combining small scale agriculture (reduced productivity due 
to topography and climate) with transhumant ranching (Summer in the communal alpine pastures and Winter in the private fields of the valleys or in rented lots in the low lands) and occasional seasonal wage labor (grape or wheat harvest in France, or Spanish lowlands of Lleida respectively). It overcame, with difficulty, the living conditions brought about by industrial modernity, and is now taking a look at how postindustrial life will manifest itself in its valleys and mountains. This paper describes and analyzes the contemporary situation in the valleys of the Pallars Sobirà paying special attention to the ways in which local communities and their commons cope with the systematic transformations associated with conservation policies and tourism expansion. ${ }^{1}$

This article discusses the troubled relationship between political and economic centers and its associated peripheral hinterlands in an unorthodox locale, the rural areas of the Western world (Sivaramakrishnan and Vaccaro 2006). This localization allows us to move beyond the traditional analytic dichotomy that opposes metropolises and colonies or postcolonial countries to urban-to-rural networks. This is a discussion about the cultural changes brought upon by socioeconomic transformations associated to market integration and economic globalization. This research builds on a long tradition of studies on the core-periphery dependency relations (Wallerstein 1974; Frank 1969), its associated uneven development (Harvey 1996; Smith 1984) and the cultural dilemmas generated by the cultural friction inherent to globalization (Appadurai 1996; Clifford 1988; Hannerz 1996; Tsing 2005).

\section{History of a Peripheral Haven: Collapses and Continuities}

The last two hundred years have witnessed a complete transformation of the Pyrenees (Roura-Pascual et al. 2005; Sabartés 1998; Solé Sabarís 2004). This sparsely populated district of high mountains and narrow valleys has not always been a haven. At the turn of the nineteenth century, these valleys renowned for their natural beauty and tourism possibilities, were a relatively remote area, with a population mostly dedicated to subsistence agro-ranching activities. This mode of production, present in the area at least since the Middle Ages, fostered evenly distributed settlement patterns. Major settlements could be found in the bottom of the valleys which were conducive to agriculture and had a higher potential for connectivity with the lowlands. The ranges were nevertheless packed with small villages, hamlets, and, in some areas, isolated farms. The pre-industrialization Pyrenean landscape was alive and, in relative terms, densely populated.

Modernity, however, was not kind to these mountains. Since the beginning of the nineteenth century the emer- gence of the modern state and its territorialization policies, along with the consolidation of capitalism and industrialism in the lowlands, led to the collapse of non-monetary subsistence-oriented modes of production, as well as increasing social connectivity and the development of entirely new sets of values.

The modern Spanish state, which emerged during the second decade of the nineteenth century, underwent considerable administrative restructuring in the pursuit of greater efficiency. The state developed a series of rational and standardized criteria such as minimum demographic size, connectivity to markets, and economic viability in this pursuit. Only the local communities that complied with those criteria could reach the status of municipality and thereby receive public services. This was the first large wave of territorialization policies developed by the modern Spanish state (Braun 2002; Hannah 2000; Peluso and Vandergeist 2001). The majority of small communities did not achieve this legal status. The inhabitants of the farms and villages of the upper slopes were forced, more than ever, to go down to the valleys. As they had no access or rights to public services they had to go often to the larger villages in the valleys to buy supplies, to bring children to school, to issue all kinds of legal permits, or to search for trading and reproductive partners. Although there was no compulsory relocation, the incentives and costs were clearly there. The contemporary Pallars Sobirà is divided in fifteen municipalities. During the last one hundred and fifty years more than a hundred villages and hamlets have disappeared from the official censuses. Just a handful of them are still permanently occupied.

During the early modernization period, the Pallars Sobirà remained fairly isolated from the emerging urban Spain, on the national periphery. The main changes affecting its valleys were focused on significant population losses in favor of the lowlands. In the Pallars Sobirà which lacked its own industrialization process, these losses started as early as the final years of the nineteenth century and the beginning of the twentieth. There was no industrialization in the Pallars Sobirà to slow down the depopulation process, with the exception of a shortlived period of hydropower plant construction during the 1950s (Arqué, Garcia, and Mateu 1982; Herrera 2002). The energy obtained from the water of the mountains fueled the expansion of industrial revolution and the electricity hungry urban areas of Catalonia and Spain (Maluquer de Motes 1998). Although the dams brought jobs during the construction period, it was a mirage that quickly vanished once the dams and the hydropower plants were finished (Boneta 2003; Tarraubella 1990).

Concurrently to these socioeconomic changes, two new waves of territorialization policies were issued by the state: the disentailment campaigns (1850-1900), and the expro- 


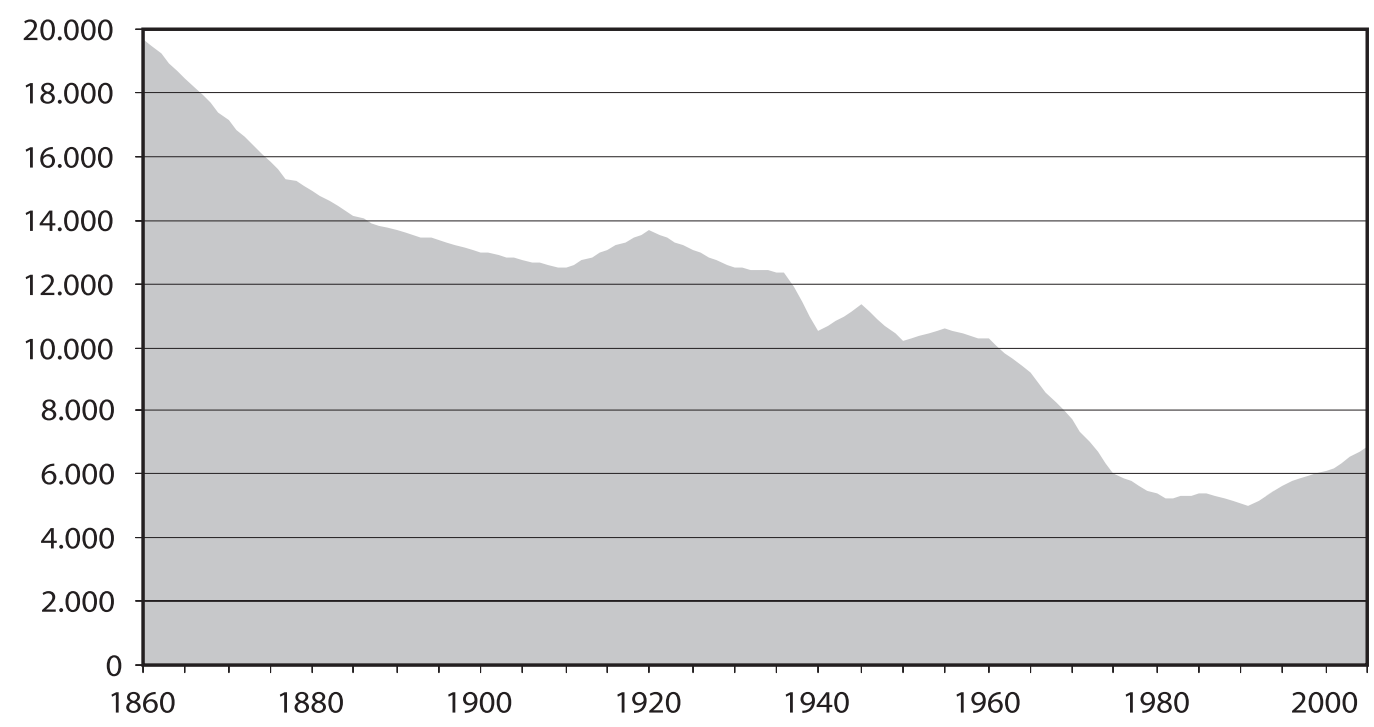

Figure 1. Demographic evolution of the Pallars Sobirà.

priation campaign led by the forest engineer corps (19001960). ${ }^{2}$ Large patches of territory became public land. In the first case, the disentailment campaign, the expropriations attempted to introduce theoretically non-productive lands into the real estate market. Common property, abundant at the time in the Pyrenees, was especially targeted (Gil 2000; Iriarte-Goñi 2002). Non-private forms of property, in the eyes of the nineteenth-century liberals, were inefficient. In the second case, the corps of engineers was given the authority to decide about the condition of the land. It was a time in which dozens of water reservoirs were being built downstream, and there was significant preoccupation about deforestation and erosion affecting the efficiency of the reservoirs: thousands of hectares were expropriated. Traditional uses of the landscape were considered harmful and the cause of erosion. The confiscated land from then on was enclosed, kept, and managed by governmental institutions. The people that had lived and worked on farms, now expropriated patches, had to relocate. Often, this meant they moved to the valley towns.

Since mid nineteenth century the slopes started to depopulate. Some villagers relocated because of the attraction power of the reemerging towns. Others relocated because the dwindling population of the upper villages did not offer a viable critical mass for a healthy community anymore. In the Pallars Sobirà the migration did not stop at the towns and villages at the bottom of the valleys. People pushed forward to the urban areas (Molina 2002; Sabartés 1993, 1998). The area experienced an acute process of depopulation and aging. Figure 1. illustrates the demographic trends described above.

These socioeconomic convulsions were not inconsequential to the environment of the Catalan mountains
(Lasanta 2002; Roura-Pascual et al. 2005). Today, the old agricultural terraces still climb impossible slopes but not much is cultivated on them. The terraces are silent evidence of an era in which these mountains were densely inhabited and where agriculture and ranching were the main productive activities. These terraces penetrate deep into the now forested area. In other words, forests were not present when these mountains were a functional agrarian landscape. The forest started to recolonize long-abandoned fields, and charismatic species, due to natural processes or to reintroduction, returned to the mountains.

This gradual abandonment prepared the stage for the next economic transformation of these mountains. The postindustrial Pyrenees are characterized by low population densities, communities mainly concentrated in villages, mountains mainly devoid of permanent inhabitants, and exuberant and growing forests. These new characteristics attracted a new wave of territorialization policies. The fourth wave since the beginning of the nineteenth century and the emergence of the modern Spanish state was characterized by the generalized implementation of conservation areas and ski resorts (Gómez 1992; Vaccaro and Beltran 2007).

The survival of large tracks of communal or municipal land on the slopes seems to have made possible the consolidation of large projects such as natural parks or ski resorts. The process of depopulation in the high valleys has resulted also in the drastic reduction of commons' owners. Due to the current low number of owners, decisionmaking processes for communal areas nowadays closely resembles those associated to private property. During the last thirty years land speculation on the account of the potential and highly rewarding new uses has become a 
habitual activity for commons' owners, local councils, and local and external investors. The extreme fragmentation of private property characteristic of the agricultural lowlands would have been a significant obstacle to any project requiring the acquiescence of numerous owners.

Ecological, adventure, and ski tourisms have resulted in a social revival of many of these areas. The relative demographic recovery observed for the last fifteen years is related to this economic transformation. ${ }^{3}$ The service industry generates significant revenue in terms of wages and benefits from land speculation. It is questionable, however, if the economic benefits are fairly distributed across the mountain communities, and if they compensate for long-term damages to the social and ecological fabric. Local communities are far from homogeneous in their approach to these economic opportunities.

This sequence of transformations changed the relationship between mountains and cities. The implementation of protected areas and ski resorts affects space more than specific resources. It consequently resulted in territorial appropriation and urbanization of the landscape for consumptive purposes. The goal may be conservation or speculation, but in both cases territory is set apart for new uses and a specific type of local development ensues (Duncan and Duncan 2004). The newly perceived beauty of these mountains, combined with the improvement of infrastructures and the creation of tourist attractions, such as parks and ski resorts, has resulted in a spectacular development of the processes of urbanization of the territory. The Pallars Sobirà has currently two closed and five functioning ski resorts.

Construction of second residences has become a massive economic sector in the area. These homes, used during weekends or short periods during the summer holidays, remain empty throughout most of the year. Rehabilitated small villages become ghost communities for all but a few weeks of the year. Apartment buildings have begun to surround towns such as Sort or Esterri d'Aneu. These nuclei are developing their own urban sprawl. The apartments, however, remain closed most of the year. The Pallars Sobirà has gone from 21 declared second residences in 1960 to 2,235 in 2001 (Campillo and Font 2004).

During the last one hundred fifty years thus, demography and agro-ranching activities experienced a sharp collapse. Common property, adapting to the new circumstances, continues to survive. The whole period is also marked by a continuous succession of territorializing state policies. Land cost, however, although highly valuable when the valleys were densely populated, experienced a clear decline associated with the emigration process. The new uses of the landscape and the area's potential for tourism are dramatically raising the property values once again.

\section{Resources and Competitions}

Environmental conflicts are, for the most part, associated to access and control over natural resources. Environmental conflicts are often the result of different social actors with different political power competing against each other in order to maximize their grip over a specific type of resource.

In the Pallars Sobirà, a few decades ago, timber was an important resource. Nowadays the low price of wood and access to cheaper and higher quality timber from elsewhere have greatly reduced the competition over forest exploitation. This factor, jointly with depopulation and agricultural abandonment, results in a generalized expansion of the forested areas in the whole district.

Currently, the two most valued resources are land and water, or rather what you can do with them (construction and hydropower). Both types of resources play a capital role on the new uses brought about by industrial modernity (hydropower plants) and by a postindustrial, services-oriented postmodernity (parks and ski resorts). The conflicts, the processes of appropriation and resistance identified in the Pyrenees have profound historical roots.

In the Pallars Sobirà land ownership is key to understanding access to new benefits generated by the new uses of the territory. This is especially interesting if we take into account that the value of land and the attachment to it had been steadily decreasing across most of the twentieth century.

\section{Lladorre}

In the first decade of the twentieth century an entrepreneur from the lowlands disembarked in headwaters of the Cardós Valley. We do not know much about the processes of negotiation and the discussions during this time. What we do know is that between 1905 and 1915 he contractually secured the water rights of several of the streams of the area. These were natural resources that for generations had been commonly managed by the inhabitants of different valley communities. He negotiated with local groups that were, allegedly, representing all the residents of these communities. The written agreements describe these transactions for at least two of the communities currently included in the municipality of Lladorre: Lladorre itself and Tavascan. The former was represented by a society of co-owners, the latter by an obscure Owners' Association (obscure because it does not appear in any other documents before that signature). The communities were conceding the rights of exploitation of their water to an outsider not for money but for electricity (100 light bulbs in Tavascan's case). 
"(He) has acquired ownership (...) of all the lakes, rivers and waters (...), as well as the right of use to built dams, channels (...) paths and roads, in whatever number, direction and needed width to the development of the projected works (...) also for the construction of trainways, funiculars, telegraphs, phones (...) understanding that he will have to respect the necessary water to take care of the private parcels that are being currently irrigated."4

These were isolated communities with, probably, a relative knowledge of the possible future implications of such a transaction. The majority of the individuals, if advised at all about this deal, were not likely to know the profit potential of their natural resources. The terms of the transaction, all the power potential of several valleys in exchange of several hundred bulbs, speaks volumes about the asymmetries contained on this commercial operation. Probably they did not foresee, either, the amount of dominion they were going to lose.

During the following years however, the deal did not translate into any tangible change in the villagers' life. The agreement had a 25 -year validity clause. If no improvements or works happened before the expiration of the accord, the concession expired. Interestingly enough during the 1920s, just a few years before the expiration date, representatives of a hydroelectric company, the Societat Anònima Energia Elèctrica de Catalunya (EEC), headquartered in Barcelona, showed up in the valley. The entrepreneur had sold his rights to them. In 1927 a minipower plant was built nearby Tavascan. It provided 22,000 watts to the community (instead of the 100 bulbs). This measure represented the fulfillment of the commitment to provide service to the local community and actualized the agreement eliminating the expiration clause. A similar deal was implemented in Lladorre.

In 1957 a major chain of events affected the area. After building dams in most of the suitable areas of the lower areas of the Noguera Pallaresa river, the hydroelectric companies fixed their eyes on the glacial cirques of the upper Catalan Pyrenees. The municipality of Lladorre has no shortage of water and steep topographic gradients. In addition the rights over the water had been cheaply 'acquired' half a century earlier. In 1958 the all powerful Forces Elèctriques de Catalunya (FECSA) absorbed EEC and the works accelerated. A village with a few hundred of inhabitants suddenly became home to more than a thousand construction workers (in specific years three thousand).

Between 1957 and 1973 (official ending of the works) several dams were created, kilometers of pipes installed, and subterranean gigantic turbine power plants were carved inside the mountains. The construction process included barracks, small industrial funiculars, paved roads, and electrification. Tons of concrete (some of it produced in situ) were unloaded on the municipality, tons of debris were dumped there too. The landscape of the area, the water cycles of the valleys, and the identity of the affected communities were also changed forever.

Amongst these infrastructures there were two dams: one almost a kilometer downstream the village of Tavascan and the other in the area of the Quanca hamlet. The resulting bodies of water flooded the only relatively significant flat lands of this area. Flat fields were scarce commodities because of their agricultural potential. In addition, they were by the river, so they were fertile. The dams abruptly put an end to this situation. All those lands and their productive potential, a relatively high part of the valleys potential, were lost under the water. The families owning those fields were expropriated in behalf of a higher good.

During this process of hydroelectric corporations' expansion, the local communities ended up losing their mini-power plants to the improvement of the road, in the case of Tavascan (1957), and to the forced expropriation by FECSA in the case of Lladorre (1969). Lladorre's miniplant had been donated by the co-owners association to the local council in 1963 in order to secure the provision of power service to the village. In both expropriation cases the company negotiated different power supply at low cost deals for the locals.

During the 1980 and 1990s the company claimed that each of the consumers of the municipality, public and private, were deeply indebted to them after many years of low cost provision and increased demand. In response the local council claimed that the hydroelectric corporation also owed millions to the municipality on the account of never paid taxes. During the Franco period (1939-1975) hydroelectric companies had enjoyed special status: the levels of profit were spectacular, but the distribution of this profit was relative, at best (Pérez Picazo 2004; Swyngedouw 1999; Vaccaro 2007). After years of conflicts, in 1995, an agreement between the local council and the company was reached: the mutual debt was cancelled, the local council received a substantial annual contribution from the company, and service was restored at a newly agreed price. This agreement, however, did not stop the conflicts associated to access to water and hydropower. A significant group of residents of the village of Lladorre still now do not recognize the aforementioned agreement. We will discuss the particulars and ideological background of this conflict in the next section.

\section{Espot}

In Espot, at the Escrita river valley, in the western side of the Pallars Sobirà, events unfolded in a very different way. The area in 1955 was affected by the first conservation 
policy created in this part of the country: the Aigüestortes and Sant Maurici Estany National Park. This implementation resulted in significant changes of ownership regimes and productive practices. This moment of dramatic external intervention, however, opened a window for internal access and control of resources. A significant portion of the municipality that had been in private hands for centuries became communal. ${ }^{5}$ Locals had had right of use of this area but not nominal ownership.

The formalization of this title transfer resulted on the creation of a society of residents, a communal institution that collectively managed the newly acquired commons. The society, with its own statutes, provided modern juridical existence to the commons. Interestingly enough, the situation that emerged from the declaration of the park and the simultaneous ownership changes, was kept in a state of ambiguity. The mountain became communal. It was managed by the municipality, but it had jurisdictional limits as a consequence of being inside the national park boundaries. The creation of the society also changed the rules of belonging and access to the community lands. Before the transformation, when ownership was held by outsiders, everybody in Espot and the neighboring community, Estaís, had access to the grazing areas. The transfer and the creation of the society resulted in the emergence of regulations on access and belonging. It increased the power of some segments of the community to decide about collective behavior while increasing the overall rigidity of membership and therefore use. The families that were included in the society were not all the households of the community. Inclusion in this initial pool of owners is controlled by a set of strict rules (i.e., successor of the initial members, household head married to the daughter of one of the original houses, or twelve years of residency). The mountain is managed by a public, collective institution, the local council, but it is handled as a private enterprise when citizens not included on the society's original list attempt to access the mountain. Some inhabitants from Espot and most of Estaís residents are excluded from the 'new' mountain.

The mountain, however, had also become part of a national park. The impact of declaration of the park on the local communities was not immediate. After a few years, however, timber harvesting was stopped. Hunting and fishing, although tolerated for a while longer, eventually vanished from the affected area. The picture became more complicated by the construction of several hydropower plants and a ski resort inside the municipality of Espot. The former greatly impacted the park by bringing people and jobs (only during the construction period), and failing to distribute the enormous benefits generated by the plants to local communities. The latter is the result of the negotiations between the society and the ski entrepreneurs.
Only the heads of households from the society receive a percentage of the price paid for the use of the commons.

Espot, then, presents yet another example of conflict over resources due to the redefinition of uses and values associated to natural resource management. Identity, among communities, households, and society members to name a few, was reconstructed and greatly affected access to natural resources.

\section{Montenartró}

The construction, in 1994, of three mini-power plants in the communal lands of Montenartró drastically changed the life of this little community. Montenartró is an Entitat Municipal Decentralitzada, EMD (Decentralized Municipal Entity). ${ }^{6}$ In the early 1990s Montenartró was languishing at the edge of collapse, with no more than five houses open all year long, and with most of them occupied by a single individual.

The power plants, which were affecting three different common property areas brought significant amounts of cash to the commons budget. In other words, an area that was in the final stages of depopulation suddenly started to produce significant benefits. The area had not experienced competition over ownership for decades.

Initially the EMD ruled that the benefits would be distributed by household and by number of individuals in each household (at the time, only one of the houses still harbored a multiperson household). Finally this rule was not implemented and the distribution followed the traditional way of distributing commons' benefits, exclusively by house.

Soon enough, however, people that had left Montenartró in the past and still had some connection (they come in summer to their family house), or that owned second residences there (ex-locals or newcomers), started to claim their share. The families with historical connections with the community had previously been active members of the commons. These claims were denied. The community started a process of definition, a fight, over how belonging and rights are defined. This is a process that was triggered by territorial appreciation.

Registration in the village may provide with the right to vote but may not be enough to receive a share of the commons' benefits. At some point, some of the old inhabitants that stayed in the village, because of health issues and age, had to move to the nearby town. Some changes in the commons' regulations had to be made to keep these old people, at least in part, as beneficiaries. Eventually these shifts and numerous new registrations opened the door to a new transformation: summer inhabitants with a proved familial relationship with the community were allowed to participate in the distribution of benefits. 


\section{Confronted Legitimacies}

One of the elements that quickly attracted our attention was the level of social conflict encountered in these mountains. Social conflict is often solved in courts and associated most of the time with problems of access and control of natural resources. The previous section explained the historical trajectories of some of these conflicts associated with water and land issues.

At a political level these conflicts are far more complex than simple competition over natural resources. We are witnessing a clash between at least two different types of moral and political legitimacies with different historical and social contexts. Different property regimes often carry different collective identity markers and values with them. The presence and cohabitation of diverse property regimes and the institutions that manage them are not inconsequential. The presence of different legal frameworks, moral economies in Thompson's words (1966), creates a situation of legal pluralism that results in dynamic interactions between private, common, and public property and the associated individualistic, collectivistic, and public management trends (Merry 1988).

To fully explain the social meanings that attached themselves to the environmental conflicts associated to access of water and land, we must contextualize them in the larger historical frame provided earlier on in this paper. The study of particular cases provides fundamental contextual information that has the ability to generate nuanced explanations of each specific situation. The comparison of cases, and their contextualization into larger spatial and temporal frames, highlights commonalities and implicit generic, more structural, explanations. In other words, a microstudy of the process of water issues in the upper valley of Cardós can offer rich details in relation to the chronology of each phase of the conflict, and minutiae about the individuals and families involved. The obvious temptation is to explain the conflict in terms of individuals' competition for profit and historical familial mistrust. Although these are factors that cannot be ignored, the contextualization of this water issue into larger processes such as the consolidation of the municipalization of the Spanish state, the industrialization and monetization of the mountains' society, the process of generalized depopulation of the valleys, and the agrarian regression, offers other interpretative keys to the conflict.

This section goes beyond the micropolitics of each conflict and offers structural explanations for the widespread conflict that plagues these mountains. We contend that these conflicts can also be read as the result of the clash between different perceptions and types of power and legitimacy. It is a story that describes situations of legal pluralism and institutional struggle between two different local forms of organizing the public arena: two different forms, thus, that organize politics.

These conflicts are not only explained by local communities' factionalism, but require an analysis of the institutions pushed into play, and the values that sustain each one of them. The unwavering positions of the contenders and the lack of dialogue is a consequence of the relative incommensurability of the ideological mindsets that inform their moral setups. In this section we argue that these conflicts over natural resources are also conflicts of political legitimacy in which modern public institutions compete with communal institutions for the right to represent and manage some of the community's affairs.

The political makeup of the mountain communities is composed by two clear institutional poles. On one side we have the remains, in some cases in better shape than others, of local forms of organization articulated around the management of the communal mountains. On the other side, we encounter the municipalities and the local councils, public institutions associated with the state structure. This is especially relevant when contemporary municipalities contain several communities. At several levels, thus, these representation issues are associated with identity, belonging, and legitimacy (Anderson 1991).

Some of the questions that account for the described disagreements over natural resources management are associated with: Who has the right to represent a community? To who do these resources belong? Who has the right to call himself a local with full rights? Who or what has the legitimacy to decide about all these questions? How did this situation come to be?

The consolidation of the Spanish modern state during the first half of the nineteenth century resulted in several processes of reorganization of the national territory, its natural resources, and its subjects. The late Middle Ages' convoluted and anarchic administrative structure with its multiple and sometimes overlapping sovereignty holders (church, aristocracy, the crown) was replaced by a homogenous, centralized and hierarchically organized bureaucratic structure (municipalities, provinces, state). Sovereignty was bestowed upon the citizens as a collective, and representation and legitimacy were conferred to the public institutions that embody the state.

Municipalities and their local councils became the onthe-ground representatives of the machinery of the state. The communities that were incorporated into the municipalities acquired the right to public services (schools, police, infrastructures and so on). In the mountains, the rights associated with municipalities were not extended to every single populated enclave because of economic considerations based on the size and distribution of each community. Only a few of them, the biggest and more centrally located, reached the municipality status. The 


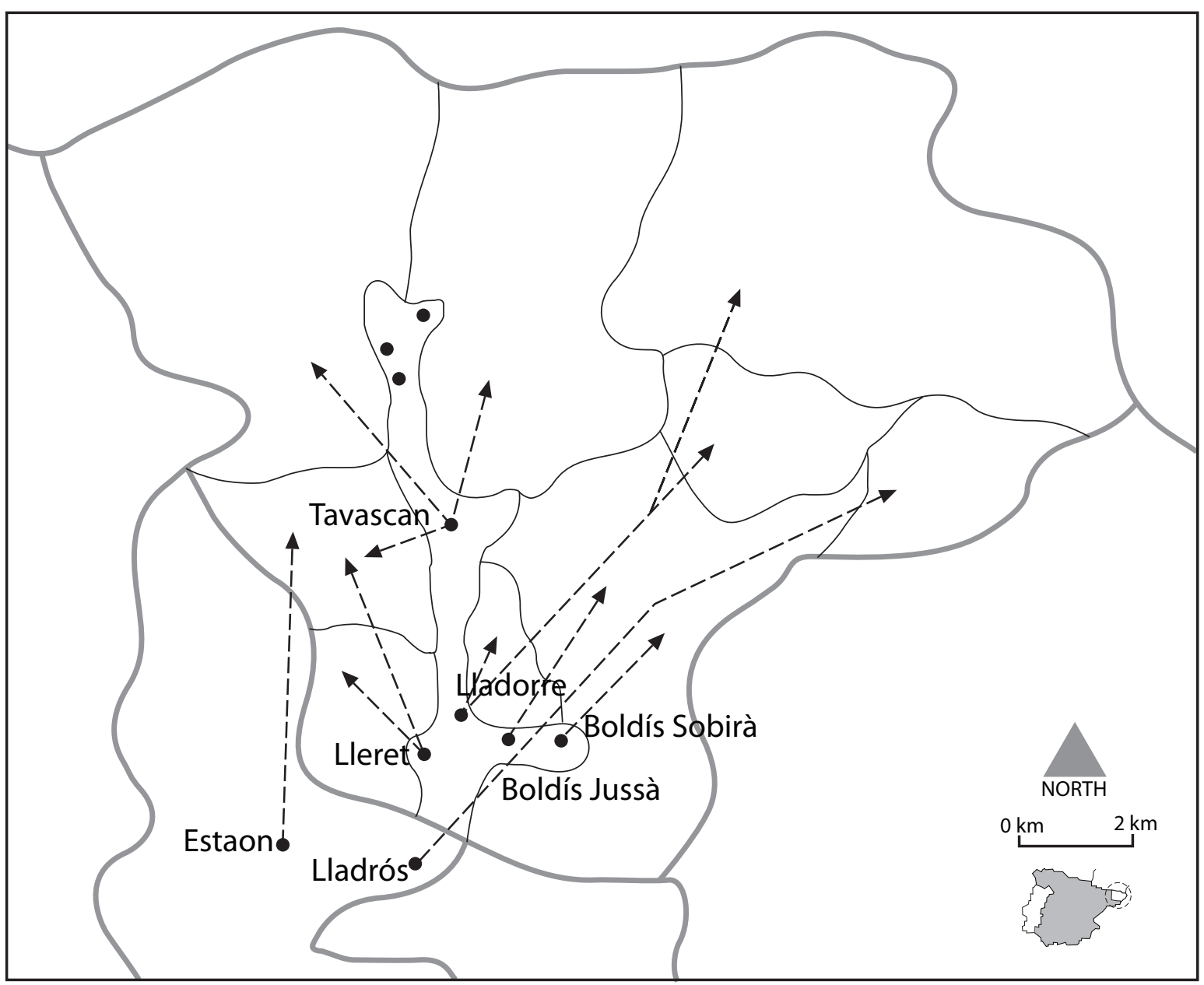

Figure 2. Map of the pasture areas of the Lladorre municipality. The arrows mark where each village of the area has pasture rights (map prepared by Joel Vaccaro)

smallest communities depended administratively on their bigger neighbors. This process was accelerated by the acute process of depopulation experienced by these mountain villages during the nineteenth and twentieth centuries. Most villages lost important contingents of their population at this time.

The district of the Pallars Sobirà has experienced a process of progressive reduction of basic administrative units. In other words, dozen of small communities have lost their administrative capabilities. Historically, however, these communities have managed their own affairs independently. The survival of common property and the local institutions that manage them are an evidence of this political and managerial autonomy. The municipality of Lladorre for instance has five communities (Lladorre, Tavascan, Boldís Sobirà, Boldís Jussà, and Lleret). Although there is only one local council, a single public interlocutor within the rest of the state apparatus, each community has their common or restricted area with exclusive or shared managerial and use rights (figure 2).

This territorial structure predates the modern organization of the state's administration and its legitimacy derives from a premodern moral economy, traditional uses and communal management of the space.

In some cases the vitality of civil society (-ies) has resulted in conflicts with public institutions. The water conflict between neighbors from Lladorre and the local council of Lladorre (currently occupied mainly by inhabitants from Tavascan) is a perfect example of political dislocation. In the previous section we saw that since the beginning of the twentieth century there have been several deals associated with water control. The early negotiations were between external actors attempting to secure different levels of access to water and power generation and local institutions representing specific, discrete communities. The major hydropower conflict of the last quarter of the century that the communities confronted was resolved with a deal between a hydropower company and local 
council. Members, or descendants, of the communities that felt they had been shortchanged with the new situation, refused to recognize the new deal, alleging that the local council could not represent them on a negotiation not started by the council, or that it should have respected their previous agreement. The company, however, refused to discuss with private collective actors. They wanted to talk to either the local council or to each private consumer. Modern commercial relationships are between institutions and corporations with particular individuals, not collectivities. This is a conflict over natural resources that is expressed in terms of legitimacy, representation, and politics. A local form of direct legitimacy is opposed to a form of legitimacy that although local in its scope, is connected to a larger network of institutions and power.

The consolidation of the state structure and the debilitation of communal institutions occurred during the same period that these areas experience a process of intense depopulation. The commons, in all their forms (collective works and decision making procedures) depended on critical mass and social capital. Depopulation greatly weakened their maneuverability and flexibility. In some cases communal lands were managed by two, three or four individuals. The reduction on numbers dismantled part of the collective essence of the commons making their functioning closer to private property than any form of collective tenure.

This collapse of collective agency, associated with a decline of agro-ranching activities and an aging population, opened the way for or forced the local councils to cover an institutional void. In many places the local councils started to manage, implicitly or explicitly, the commons. This, however, resulted in conflicts over natural resources because each municipality encompasses several, sometimes dozens, of communities. Some of these communities have kept their nominal ownership of the commons, even in cases where the village has been abandoned or almost abandoned. In such cases the heart of the problem lies on deciding entitlement. The picture in other cases is even more complex when outsiders (neo-rural) take up residence in these villages. The fact that the territory, after one hundred years of declining value, is, due to several reasons, quickly regaining and increasing its price, has brought identity and belonging to the community to the fore of discursive discussions and issues of social conflict.

The case of Montenarto, for instance, shows that conflict appears connected to identity and rights. It is also about how the integration of a marginal area into a market economy changes the value of its resources and, concomitantly, the behavior of its stakeholders. In this case, the revaluation of the territory and associated rights was triggered by the construction of mini power plants. These mountains are full of similar cases in which the catalyzer is a ski resort, the expansion of second residences, or, in the past, the sharing of timber harvesting benefits. In these case studies we see how communities begin to fight over how to define belonging because belonging has come to define access to different benefits. Are the families that resisted and persisted through the more difficult economic periods the only ones entitled to the current benefits produced by the commons? Are the descendants of those that left and are coming back, albeit seasonally, permitted to rejoin with full rights? Are those occupying second residences supposed to have a say in how the community should manage its businesses? Are the new permanent residents, with no previous connections to the village, supposed to gain full residential rights?

These are not inconsequential questions. They define the framework of competition surrounding ownership, and the conditions limiting access to natural resources: competition that, depending on the perspective, is defined on terms of appropriation, preservation, or expropriation.

The problem, again, is defined in terms of legitimacy. Outsiders see the regulations against non-local access to natural resources or to decision-making capability as an abuse. Locals see these regulations like a legitimate tool to protect their inheritances. In some cases registration of outsiders has changed the demographic and political balance of a community, marginalizing locals and their priorities. The values held by second residence people are often very different from those that inform local agency. The ethical issues become more apparent when long term residents are excluded or are not accepted as villagers with all their rights.

Lleret, for instance, is a small village atop of a ridge at 1,381 meters above the sea level and it was almost completely abandoned in 1967. At that time it was an isolated community with no roads connecting it to the valley. A few years later neo-rural populations started to resuscitate the village. At the time of repopulation, the abandoned community, fields and valleys, however, had become an open pasture for the herds of the neighboring villages. The neo-rural reopening of some of the houses of Lleret did not, for several years, restore the integrity of an urban area and cattle roamed through its streets for years. Eventually, after 10 years, and intervillage tensions the animals were removed from the streets and most of the fields.

In the village of Espot we observe how conflict can deploy itself in institutional terms. Its specificity lays in the fact that a communal institution is created to manage a new pool of available resources. In this case, however, the same social group plays with the ambiguities of municipality versus commons in order to secure control when facing different contenders. 


\section{Conclusion}

In this paper we have described specific conflicts emerging around natural resource management in some local communities of the Pallars Sobirà district. Our goal is not to solve these conflicts by ascertaining who is right or who is wrong, but to contextualize them to understand the deep social processes interlinked. We want to devote these final lines to a few considerations on continuity and newness.

The existence of conflict itself seems to be a constant in these mountains. Across history these mountains have been the stage of abundant litigation associated to access and control of natural resources. The intensity and nature of these conflicts, however, have changed depending on variables such as demographic history or predominant productive practices.

The demands placed on natural resources have an unquestionable impact on territorial value. Demand, in these mountains, is associated to use intensity. This intensity may vary depending on pressure exerted on resources. During the nineteenth century, individuals implicated in subsistence agricultural economies, applied low demands over the territory. The relatively high density however, resulted in an intense use of the territory. The demographic decay experienced by the Pallars Sobirà during the twentieth century diminished the pressure over the landscape and, consequently, the value of the territory.

The arrival of hydroelectric companies changed these terms. Populations were leaving but areas with high potentials for hydroelectric generation became valuable in a way that was not always evident to the local communities. The demands on specific natural resources were high but very concentrated. The areas that were not associated with these energy production pools remained peripheral and, thus, their value plummeted.

The emergence of conservation policies, ski resorts, second residences, and ecotourism has changed these dynamics. These phenomena have re-launched the potential value of the Pyrenean territory and, especially, of its habitable space: dozens if not hundreds of abandoned houses are in the process of being reconstructed and hundreds if not thousands of new homes are being built, mostly for the second residence market.

As we have seen, an interesting consequence of these territorial value changes is the reverberation over identity and belonging. The revalorization of dimly or unclearly claimed resources has opened all sorts of discussions over who owns and who has the rights to benefit from these natural resources. This debate also discusses the legitimacy of the different institutions that manage and represent resources and citizens in these mountains.

\section{Endnotes}

1 This ongoing project has been carried thanks to the support of the Inventari del Patrimoni Etnologic de Catalunya (IPEC), the research group Globalización y Producción de Localidad and project Procesos de patrimonialización de la naturaleza y la cultura CSO2008-05065/SOCI from the Universitat de Barcelona and funded by the Ministerio de Educación y Ciencia. Our thanks to them and to the dozens of individuals and local institutions from the Pallars Sobirà that kindly collaborated with us, allowing us to interview them, to be part of their professional activities, or that provided documentation to us.

2 To learn more about the local consequences of such policies see Gómez (1992) and Vaccaro (2005)

3 The Pallars Sobirà has gone from 5,046 to 7,191 inhabitants between 1991 and 2007, after four decades of negative demographic growth. See figure 1.

4 Contract of water rights' transference, 1914, pages 1 and 2 (not numbered in the original). Translated by the authors.

5 The mountain had belonged to the aristocracy (Pallars' Counts first, and the Medinaceli Dukes later) until the mid-nineteenth century, and had passed to a wealthy industrial family until 1957.

6 EMDs are special administrative units, inhabited centers separated from the capital of the municipality, with distinctive characteristics. EMDs have their own public juridical category and a certain degree of autonomy in relation to the provision of services to their residents.

\section{References}

Appadurai, A.

1996 Modernity at Large: Cultural Dimensions of Globalization (University of Minnesota Press, Minneapolis)

Anderson, B.

1991 Imagined Communities (Verso, London)

Arqué, M., A. Garcia, and X. Mateu

1982 "La penetració del capitalisme a les comarques de l'Alt Pirineu" Documents d'Anàlisi Geogràfica, 1 9-67

Boneta, $\mathrm{M}$. 2003 La Vall Fosca: els llacs de la llum. Desenvolupament socioeconomic a començament del segle XX (Garsineu Edicions, Tremp)

Braun, B.

2002 The Intemperate Forest: nature, culture and power in Canada's West coast (Minnesota University Press, Minneapolis) 
Campillo, X. and X. Font

2004 Avaluació de la sostenibilitat del turisme a l'Alt Pirineu i Aran (Generalitat de Catalunya, Barcelona)

Clifford, J.
1988

1988 The Predicament of Culture (Harvard University Press, Cambridge)

Duncan, J., and N. Duncan

2004 Landscapes of Privilege (Routledge, London)

Frank, A.G.

1969 Latin America: Underdevelopment or Revolution (Monthly Review Press, New York)

Gil, X.

2000 La desamortització dels béns comunals al Pallars Sobirà. El cas de Llessui (Garsineu Edicions, Tremp)

Gómez, J.

1992 Ciencia y política de los montes españoles

(1848-1936) (ICONA, Madrid)

Hannah, M.

2000 Governmentality and the Mastery of the

Territory in Nineteenth Century America

(Cambridge University Press, Cambridge)

Hannerz, U,

1996 Transnational Connections: Culture, People, Places (Routledge, London)

Harvey, D,

1996 Justice, Nature and the Geography of Difference (Blackwell, Oxford)

Herrera, A.

2002 "Infraestructuras y desarrollo económico en

el Pirineo central (1850-2000)" Ager. Revista de Estudios sobre Despoblación y Desarrollo Rural 2 197-226

Iriarte-Goñi, I.

2002 "Common lands in Spain, 1800-1995: persistence, change and adaptation” Rural History 13 (1): 19-37

Lasanta, T.

2002 "Los sistemas de gestión en el Pirineo central español durante el siglo XX: del aprovechamiento global de los recursos a la descoordinación espacial en los usos del suelo" Ager. Revista de Estudios sobre Despoblación y Desarrollo Rural 2 173-195

Maluquer de Motes J.

1998 Història econòmica de Catalunya: segles XIX i XX (Proa, Barcelona)

Merry, S.

1988 “Legal Pluralism” Law \& Society Review 22: 869-896
Molina, D.

2002 "El proceso de desertización demográfica de la montaña pirenaica en el largo plazo: Cataluña” Ager. Revista de Estudios sobre

Despoblación y Desarrollo Rural 2 81-100

Peluso, N., and P. Vandergeist

2001 "Genealogies of the Political Forest and Customary Rights in Indonesia, Malaysia and Thailand" Journal of Asian Studies 61 761-812

Pérez Picazo, M.T.

2004 "De Costa al paradigma del desarrollo sostenible. Claves históricas de una crisis." In Arrojo, P. et altri. El Agua en España: propuestas de futuro (Ediciones del Oriente y el Mediterráneo, Madrid)

Roura-Pascual, N., P. Pons, M. Etienne, and B. Lambert 2005 "Transformation of a rural landscape in the Eastern Pyrenees between 1953 and 2000" Mountain Research and Development 25 (3): 252-261

Sabartés, J.M.

1993 L'Ėxode Pallarès: crisi demogràfica i devallada poblacional als Pallars i l'Alta Ribagorça (1857-1991) (Garsineu Edicions, Tremp)

Sabartés, J.M.

1998 Població i territori a l’Alt Pirineu català (Garsineu Edicions, Tremp)

Sivaramakrishnan, K., and I. Vaccaro

2006 "Postindustrial Natures: Hyper-mobility and Place Attachments" Journal of Social Anthropology 14 (3): 301-317

Smith, N.

1984 Uneven Development; Nature, Capital and the Production of Space (Blackwell, Oxford)

Solé Sabarís, L.

2004 El Pirineu. El medi i l'home (Garsineu Edicions, Tremp)

Swyngedouw, E.

1999 "Modernity and Hibridity: nature, Regeneracionismo, and the Production of the Spanish Waterscape, 1890-1930" Annals of the Association of American Geographers, 89 (3): 443-465

Tarraubella, X.

1990 La Canadenca al Pallars (Garsineu Edicions, Tremp)

Thompson, E.P.

1966 The Making of the English Working Class (Vintage Books, New York) 
Tsing, A. 2005

Friction: an Ethnography of Global Connection (Princeton University Press, Princeton)

Vaccaro, I.

2005 "Property mosaic and state-making: governmentality, expropriation and conservation in the Pyrenees" Journal of Ecological Anthropology 9 4-19

Vaccaro I. 2007

"Modernizing water: state, industry and territory" in Perry, R, Ingram, H. and Whiteley, J. Water, Place and Fairness: Tempering Efficiency with Equity (MIT Press, Massachussets)
Vaccaro, I., and O. Beltran

2007 "Consuming space, nature and culture: patrimonial discussions in the hyper-modern era" Tourism Geographies 9: 254-275

Wallerstein, I.

1974 The Modern World System (Academic Press, New York) 